\title{
Efficacy of Gastric Electrical Stimulation for Gastroparesis: US/European Comparison
}

\author{
Jordan Burlen ${ }^{\mathrm{a}}$, Matt Runnels ${ }^{\mathrm{b}}$, Minesh Mehta ${ }^{\mathrm{a}}$, Stina Andersson ${ }^{\mathrm{c}}$, Philippe Ducrotte ${ }^{\mathrm{d}}$, \\ Guillaume Gourcerol $^{\mathrm{d}}$, Greger Lindberg ${ }^{\mathrm{e}}$, Greg Fullarton ${ }^{\mathrm{f}}$, Hasse Abrahamsson ${ }^{\mathrm{c}}$, \\ Amar Al-Juburi ${ }^{\mathrm{g}}$, Chris Lahr ${ }^{\mathrm{h}}$, Hani Rashed ${ }^{\mathrm{i}}$, Thomas Abella, j
}

\begin{abstract}
Background: Gastric electrical stimulation (GES) is used in both the US and Europe, but little research has investigated the demographics of gastroparesis patients receiving GES by geographic location.

Methods: We compared data from 380 patients, 296 female and 84 males, mean age 42 years, 246 idiopathic (ID), 107 diabetic (DM), and 27 post-surgical (PS). The statistical significance was calculated by Chi-square test and a P-value obtained for ID, DM, and PS. The statistical significance was calculated by Fischer exact test and a Pvalue obtained comparing male vs. female.
\end{abstract}

Results: European centers had 61 GES patients compared to 319 from the US. In Europe, $100 \%$ of patients had gastric emptying test (GET) values available; in the US, it was $75 \%$ of patients. European centers had more DM patients (59\%) than the US (22\%), and a smaller proportion of ID patients $(25 \%)$ than the US (72\%). There was a statistical difference between the causes of gastroparesis in the patients receiving GES (P-value $<0.00001$ ). There was also significant difference in the gender of the patients receiving GES, with a greater proportion of women in the US $(P$ value $=0.0023)$.

Conclusions: Comparing GES in US vs. Europe demonstrated significant differences in gastroparesis demographics and percentage of patients with GET data. After analyzing the previously discussed results and reviewing recent updates in evidence-based medicine guidelines, the discrepancy and variance in patient populations in the US and Europe emphasizes the need for a database that allows better

Manuscript submitted July 3, 2018, accepted July 26, 2018

aUniversity of Louisville, Louisville, KY, USA

${ }^{\mathrm{b}}$ Gastrodocs.net, Jackson, MS, USA

'University of Goteborg, Sweden

dRouen University Hospital, Rouen, France

eKarolinska University Hospital, Stockholm, Sweden

fUniversity of Glasgow, Glasgow, Scotland

gUniversity of Arkansas for Medical Sciences, Little Rock, AR, USA

hMedical University of South Carolina, Charleston, SC, USA

iUniversity of Tennessee, Memphis, TN, USA

${ }^{\mathrm{j} C}$ Corresponding Author: Thomas L. Abell, Division of Gastroenterology, Hepatology, and Nutrition, University of Louisville, 550 S. Jackson Street, ACB3 A3L15, Louisville, KY 40202, USA. Email: thomas.abell@louisville.edu

doi: https://doi.org/10.14740/gr1061w analysis and treatment of gastroparesis patients worldwide including stimulation therapies.

Keywords: Gastroparesis; Nausea and vomiting; Gastric electrical stimulation; Diabetes; Health delivery

\section{Introduction}

Gastroparesis is characterized by clinical symptoms that may consist of bloating, anorexia, nausea, vomiting, early satiety and abdominal pain [1-3]. The etiology of gastroparesis is varied and includes diabetic, idiopathic, viral, autoimmune, and post-surgical gastroparesis $[2,3]$. Often patients present with concomitant overlap syndromes, consisting of migraine headaches, interstitial cystitis, fibromyalgia, and systemic hypercoagulability [4-6]. The diagnosis is based on clinical presentation, full-thickness gastric biopsy, electrophysiological recording, and radionuclide emptying studies [7, 8]. Initial screening and diagnosis of gastroparesis rely on distinguishing the patient's symptom pattern as chronic or cyclic; this is a separate entity from cyclic vomiting syndrome $[4,9]$. Up to $50 \%$ of diabetic gastroparesis patients, and many idiopathic gastroparesis patients, have a cyclic pattern [4]. Family history assessment is important, especially in the assessment of overlapping diseases, such as cyclic vomiting, clotting disorders, migraine, fibromyalgia, interstitial cystitis, bladder dysfunction, endometriosis, and depression [6,10]. It is also important to be able to differentiate gastroparesis from gastroparesis like syndrome (GLS). These two diseases are incredibly difficult to differentiate by gastric emptying testing (GET) alone [11]. Recent investigations into distinguishing the two based on interstitial cells of Cajal (ICC) loss and fibrosis of the pylorus (with gastroparesis patients having worse features comparatively) are proving as better methods to determine which patients would benefit from more invasive therapies [12]. These diseases may have an impact on outcome, but not always a negative one for gastric electrical stimulation (GES) patient selection.

GES is an accepted therapy for drug-refractory gastroparesis; however, reports of efficacy have varied among centers. We aimed to compare the efficacy and the cause of GES at different centers from around the world using the latest comparative data available. 

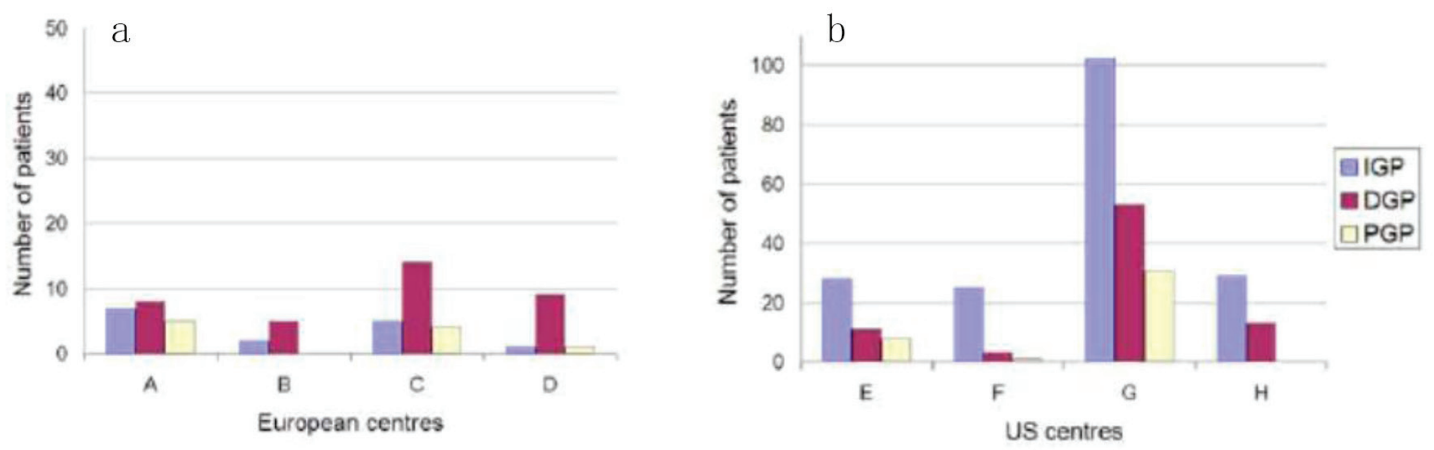

Figure 1. The European centers (a) has a larger mean proportion of DGP patients compared to US centers (b) (59\% vs. $22 \%)$ and a smaller mean proportion of IGP patients ( $25 \%$ vs. $72 \%)$. The figures show the number of patients (IGP, DGP, PGP) at each centre $(\mathrm{A}-\mathrm{H})$.

\section{Materials and Methods}

Consecutive patients with symptoms of gastroparesis who had gastric electric stimulators placed were evaluated at several centers in Western Europe and the US (Fig. 1a, b). The centers were selected by availability of data and willingness to share the results of evaluation and treatment. Seventy-five percent of US patients did not have formal GET studies, as there was not a standardized procedure in place at one of the US centers. For each center, the patients were recorded by: demographics (age and sex); underlying diagnosis (idiopathic gastroparesis (IGP), diabetic gastroparesis (DGP), and post-surgical gastroparesis (PGP)); percentage of centers where GET criteria were used; months since implant; percentage change gastrointestinal total symptom score (TSS). TSS included nausea, vomiting, anorexia/early satiety, bloating/distention, and abdominal pain, with a maximum score of 20 . Data were normalized to a standardized scale if needed for analysis. Raw data were compared for the previously mentioned data points. Statistical significance was evaluated by Fischer exact test and P-value obtained for gender differences. Statistical significance was evaluated by Chi-square test and P-value obtained comparing IGP, DGP, and PGP. Each center had full regulatory and/or IRB approval for their site. All patients underwent informed consent as required by their respective institutions.

\section{Results}

Three hundred and eighty patients were available for analysis from eight centers (four in the US and four in Europe). Out of 380 total patients, there were 296 females and 84 males with a mean age of 42 years. The details of US vs. Europe are noted in Table 1. The proportion of males to females was 1:4.2 in the US centers, while it was 1:1.7 in the European centers. There were 246 patients with IGP, 107 patients with DGP, and 27 patients with PGP. All of the European centers had baseline gastric emptying data on each patient studied, while $75 \%$ of the patients studied at the US centers had baseline gastric emptying data recorded. The European patients were followed for a mean of 35 months after implant and the US centers followed the patients for a mean of 49 months after GES implant. Vomiting was decreased by $62 \%$ after GES implant in the European centers and by $45 \%$ in the US centers. In the European centers, the patients' TSS was decreased by $48 \%$, while the US study population had a decrease of $38 \%$ in their TSS after GES implant.

In Table 2, the gender characteristics of the patient populations in the US were compared to the European centers to determine if there was a significant difference. There was a significant difference in the gender populations between the two $(\mathrm{P}<0.05)$. In Table 3 , the number of patients with the three analyzed categories of gastroparesis was compared to assess for significant difference in the patient populations. There was noted to be a significant difference in etiology between the two regions $(\mathrm{P}<0.05)$.

\section{Discussion}

This brief report is the first comparison of implantation of gastric electrical stimulators between the US and Europe. Many

Table 1. Data From US and European Centers

\begin{tabular}{lllllllllll}
\hline Center & Number of patients & Sex: $\mathbf{F}$ & Sex: M & Age & IGP & DGP & PGP & GET & Months & Change in TSS \\
\hline Europe & 61 & 38 & 23 & 41 & 15 & 36 & 10 & $100 \%$ & 35 & -48 \\
US & 319 & 258 & 61 & 42 & 231 & 71 & 17 & $75 \%$ & 49 & -38 \\
Combined & 380 & 296 & 84 & 42 & 246 & 107 & 27 & $88 \%$ & 47 & -38.5 \\
\hline
\end{tabular}

The proportion of males to females was 1:4.2 in the US and 1:1.7 in Europe. Values for GET, months since implant, change in vomiting, and change in total symptom score (TSS) are presented as means. IGP: idiopathic gastroparesis; DGP: diabetic gastroparesis; GET: gastric emptying test; F: female; M: male. 
Table 2. Fisher Exact Test to Determine Gender Differences in Gastroparesis Patients by Region

\begin{tabular}{lllll} 
& Male & Female & Totals & P-value $(<\mathbf{0 . 0 5})$ \\
\hline Europe & 23 & 38 & 61 & \\
United States & 61 & 258 & 319 & \\
Totals & 84 & 269 & 380 & $<0.05$ \\
\hline
\end{tabular}

of the patients appear similar in terms of GI symptoms and in age from the available data; however, sex distribution favors females in the US vs. Europe. Several other important differences are noted between the US and Europe from the numbers reported here. First, there are many more GES implants reported in the US than Europe. Secondly, the use of baseline GETs seems to be reported more, at least in this series, in Europe than the US. This is especially interesting, because $25 \%$ of GES patients in the US did not have a standardized GET study. Third, the percentage of diabetic patients implanted in Europe is higher than in the US.

It is becoming increasingly apparent that there is a difference in the manner by which patients are diagnosed, treated, and monitored in the US vs. Europe. Figure 2 details the algorithm by which gastroparesis patients are assessed and treated in the US vs. Europe, with differences highlighted in bold [13-15]. It should be noted that the difference between the two methodologies is that domperidone is approved and used in the treatment of gastroparesis in Europe but is not formally approved by the FDA in the US.

Recent investigations into the mechanism of gastroparesis have found that the loss of the ICC play a major role in pathogenesis. Their function is to regulate smooth muscle contractility by modulating slow wave progression $[13,14]$. Recent studies have shown a reduction in these cells in biopsies of patients with gastroparesis. With this in mind, a literature investigation into the effectiveness of GES in treating gastroparesis was performed. Five meta-analyses and seven controlled trials were highlighted discussing GES as a treatment modality for gastroparesis (Tables 4 and 5) [16-28]. There was a generally favorable assessment of GES as a treatment for refractory gastroparesis (Table 5) [21-28].

As more GES devices are implanted worldwide, the need for an international registry is apparent. This would allow for increased standardization and comparison of outcomes in these patients. Having these data would allow for improved selection of appropriate candidates for GES $[16,17]$. The lack of up-to-date data shows some of the difficulties in obtaining comparative data. Several recent articles have shown activities in both the US and Europe that may eventually lead to

Table 3. Difference Between the Etiologies of Gastropathy Treated with GES by Region

\begin{tabular}{llllll}
\hline & IGP & DGP & PGP & Totals & P-value $(<\mathbf{0 . 0 5})$ \\
\hline Europe & 15 & 36 & 10 & 61 & \\
United States & 231 & 71 & 17 & 319 & \\
Totals & 246 & 107 & 27 & 380 & $<0.05$ \\
\hline
\end{tabular}

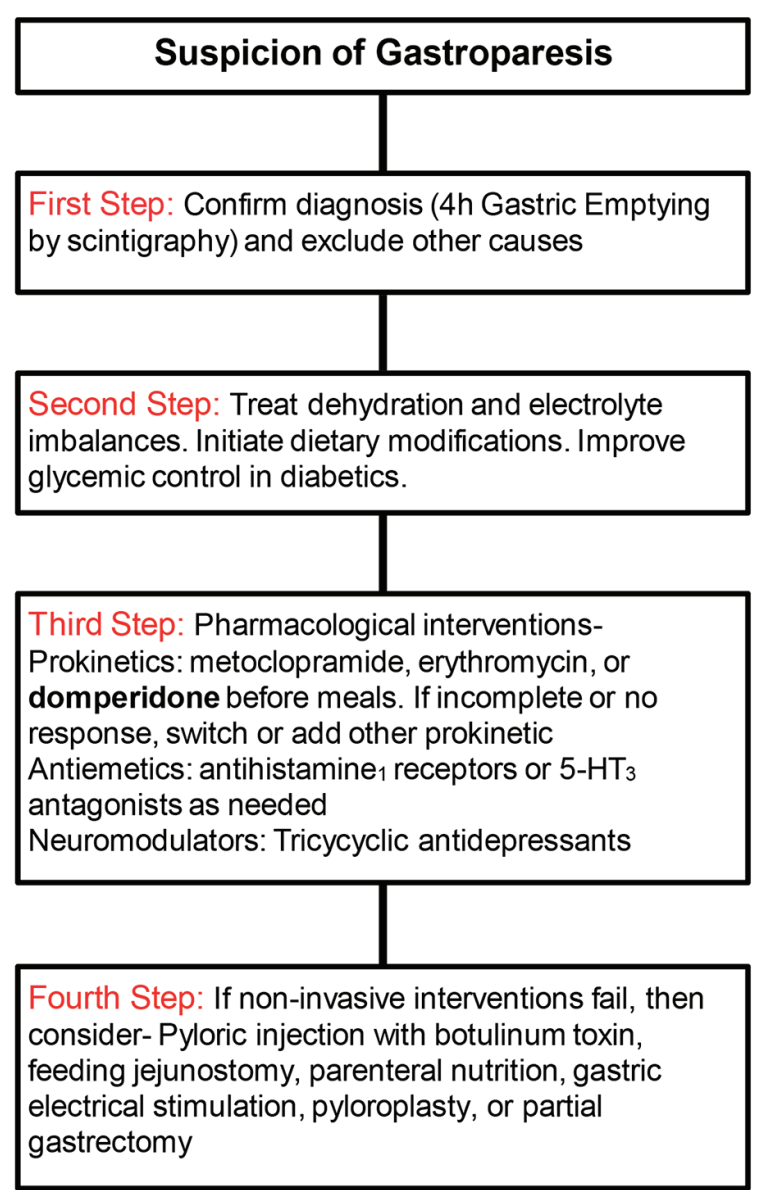

Figure 2. Algorithm for diagnosis and treatment of gastroparesis in US vs. Europe (European differences in bold).

new advances in GES technology [29]. In addition, other new technologies, such as full thickness gastric biopsies and gastric electrical mapping, may reveal a better understanding of the underlying pathophysiology of gastroparesis, and this too may lead to advances in GES technology [30].

Further investigation and clarification is needed in differentiating GLS from functional dyspepsia (FD). GLS is defined as gastroparesis-like symptoms with normal gastric scintigraphy [31]. FD is defined by the Rome IV criteria and must include: 1) bothersome postprandial fullness, early satiation, epigastric pain, or epigastric burning and 2) no evidence of structural disease (including at upper endoscopy) that is likely to explain the symptoms. These criteria must be fulfilled for the last 3 months with symptom onset at least 6 months prior to diagnosis [32]. There is substantial overlap between these two diagnoses, and, in the literature, there is occasionally even mention of FD with delayed GET [33]. This displays the difficulty in categorizing this disease process. The use of FD vs. GLS when discussing gastroparesis type symptoms with normal GET appears to vary based on geographical location, with FD being used more frequently in Europe and GLS more often in the US. There seems to be a growing movement away from categorizing these as separate entities, and rather as being along a spectrum of disease 
Table 4. Metanalyses Assessing Effectiveness of Gastric Electrical Stimulation

\begin{tabular}{lll}
\hline Study title & Authors & General conclusion \\
\hline $\begin{array}{l}\text { NICE guidance on gastroelectrical } \\
\text { stimulation for gastroparesis }\end{array}$ & Kong (2015) [17] & $\begin{array}{l}\text { Severe diabetics with severe symptoms } \\
\text { may benefit from therapy. }\end{array}$ \\
$\begin{array}{l}\text { High-frequency gastric electrical stimulation for } \\
\text { the treatment of gastroparesis: a meta-analysis }\end{array}$ & O'Grady et al (2009) [20] & $\begin{array}{l}\text { Beneficial in improving symptoms } \\
\text { in patients with gastroparesis. }\end{array}$ \\
$\begin{array}{l}\text { Systematic review and meta-analysis: gastric } \\
\text { electrical stimulation for gastroparesis }\end{array}$ & Levinthal et al (2017) [19] & $\begin{array}{l}\text { Argues against the use of GES outside of strict } \\
\text { clinical trials as viable treatment option. }\end{array}$ \\
$\begin{array}{l}\text { Gastric electrical stimulation with the } \\
\text { Enterra system: a systematic review }\end{array}$ & Lal et al (2015) [16] & $\begin{array}{l}\text { GES appears to offer significant improvement } \\
\text { in symptom control in a subset of patients. }\end{array}$ \\
$\begin{array}{l}\text { Treatment of high-frequency gastric } \\
\text { electrical stimulation for gastroparesis }\end{array}$ & Chu et al (2012) [18] & $\begin{array}{l}\text { GES is an effective modality for treating } \\
\text { gastroparesis refractory to less invasive treatment. }\end{array}$ \\
\hline
\end{tabular}

[33]. Recent studies have demonstrated patient improvement in symptom scores for FD and GLS with medical management and even GES in patients with symptoms of gastroparesis but normal GET $[31,34]$. Further refinement and determination of specific definitions would allow for a more uniform treatment pattern for patients. By this, perhaps better and more effective treatments could be achieved.

An additional factor in future treatment of gastroparesis will be the emerging role of pyloric therapies in the treatment of gastroparesis, especially in patients with markedly delayed gastric emptying and who are refractory to other therapies. These possible future interventions include gastric peroral endoscopic pyloromyotomy (G-POEM), the process by which the plyoric muscles are endoscopically incised [35]. There has been recent investigation into this procedure as a viable option for refractory gastroparesis, and perhaps offers another means by which to treat this disease $[36,37]$. Though this is a promising intervention, it has not been rigorously studied or evaluated, and, like GES, would also benefit from an international database for more comprehensive investigation [38].

\section{Conclusions}

This is the first international trial comparison of the use of GES for patients with the symptoms of gastroparesis confirming ef-

Table 5. Controlled Trials Assessing Effectiveness of Gastric Electrical Stimulation

\begin{tabular}{|c|c|c|}
\hline Study title & Authors & General conclusion \\
\hline $\begin{array}{l}\text { A double-masked, randomized, placebo-controlled } \\
\text { trial of temporary endoscopic mucosal gastric } \\
\text { electrical stimulation for gastroparesis }\end{array}$ & Abell et al (2011) [23] & $\begin{array}{l}\text { Temporary GES may improve } \\
\text { symptoms such as vomiting. }\end{array}$ \\
\hline $\begin{array}{l}\text { Gastric electrical stimulation is associated with } \\
\text { improvement in pancreatic exocrine function in humans }\end{array}$ & Luo et al (2004) [25] & $\begin{array}{l}\text { GES had noted effects on autonomic control, } \\
\text { improvement in exocrine pancreatic enzyme } \\
\text { release, and improvement in GI symptoms. }\end{array}$ \\
\hline $\begin{array}{l}\text { Gastric electrical stimulation for } \\
\text { medically refractory gastroparesis }\end{array}$ & Abell et al (2003) [22] & $\begin{array}{l}\text { GES set to high-frequency/low-energy decreased } \\
\text { vomiting frequency and GI symptoms. }\end{array}$ \\
\hline $\begin{array}{l}\text { Gastric electrical stimulation with Enterra therapy } \\
\text { improves symptoms of idiopathic gastroparesis }\end{array}$ & McCallum et al (2013) [26] & $\begin{array}{l}\text { GES implanted with ON stimulation was } \\
\text { shown to decrease vomiting symptoms } \\
\text { and days of hospitalizations. }\end{array}$ \\
\hline $\begin{array}{l}\text { Gastric electrical stimulation with Enterra } \\
\text { therapy improves symptoms from diabetic } \\
\text { gastroparesis in a prospective study }\end{array}$ & McCallum et al (2010) [27] & $\begin{array}{l}\text { GES for } 6 \text { weeks significantly reduced } \\
\text { vomiting and gastroparetic symptoms } \\
\text { for diabetic gastroparesis. }\end{array}$ \\
\hline $\begin{array}{l}\text { Effectiveness of gastric electrical stimulation in } \\
\text { gastroparesis: results from a large prospectively } \\
\text { collected database of a national gastroparesis registry }\end{array}$ & Abell et al (2015) [24] & $\begin{array}{l}\text { Patients treated with GES had clinically significant } \\
\text { improvement in gastroparesis symptoms. }\end{array}$ \\
\hline $\begin{array}{l}\text { Gastric electrical stimulation (GES) for refractory } \\
\text { vomiting: results of a prospective multicenter double- } \\
\text { blinded randomized controlled cross-over trial }\end{array}$ & Ducrotte et al (2017) [21] & $\begin{array}{l}\text { GES was associated with significant } \\
\text { reduction of symptoms in both diabetic } \\
\text { and non diabetic gastroparesis patients. }\end{array}$ \\
\hline $\begin{array}{l}\text { Is gastric electrical stimulation superior to standard } \\
\text { pharmacologic therapy in improving GI symptoms, } \\
\text { healthcare resources, and long-term healthcare benefits? }\end{array}$ & Cutts et al (2005) [28] & $\begin{array}{l}\text { GES was found to be more effective } \\
\text { in improving long-term GI symptoms, } \\
\text { decreased costs, and less use of healthcare } \\
\text { resources than intensive medical therapy. }\end{array}$ \\
\hline
\end{tabular}


fectiveness of GES. The specific localities studied, both US and Europe, reveal similarities but also differences between centers, particularly with respect to diabetic to IGP proportions. Ongoing prospective comparisons of outcome data are feasible and may be warranted with the continued clinical use of GES. In addition, the need for an up-to-date, hopefully online, database in registry format for international GES implants seems apparent.

\section{Acknowledgments}

The authors would like to thank the staff of their respective institutions for help in the collection of this data. They would also like to thank the University of Mississippi Medical Center, where some of the data was collected. They would like to thank Catherine McBride at the University of Louisville for help with manuscript preparation. This study was completed without an external funding source.

\section{Author Contributions}

Jordan Burlen, Minesh Mehta, and Matt Runnels: data analysis, manuscript preparation. Stina Andersson, Philippe Ducrotte, Guillaume Gourcerol, Greger Lindberg, Greg Fullarton, Hasse Abrahamsson, Amar Al-Juburi, Chris Lahr, Hani Rashed, and Thomas Abell: manuscript design, data acquisition, data analysis, manuscript preparation.

\section{Conflict of Interest}

Dr. Abell was an investigator, consultant and licensor to Medtronic when this data was collected.

\section{Disclosures}

EXACTS (European Across American Comparative Trial of Stimulation) is formed by: ASSESS (Associated Southern Sites of Electrical Stimulation Studies): T. Abell, M. Runnels, A. Al-Juburi, C. Lahr, H. Rashed, J. Burlen, M. Mehta; and EDGES (European Data of Gastric Electrical Stimulation): H. Abrahamsson, S. Andersson, P. Ducrotte, G. Gourcerol, G. Fullarton, G. Lindberg.

\section{References}

1. Malagelada JR, Stanghellini V. Manometric evaluation of functional upper gut symptoms. Gastroenterology. 1985;88(5 Pt 1):1223-1231.

2. Hornbuckle K, Barnett JL. The diagnosis and work-up of the patient with gastroparesis. J Clin Gastroenterol. 2000;30(2):117-124.

3. Soykan I, Sivri B, Sarosiek I, Kiernan B, McCallum RW. Demography, clinical characteristics, psychological and abuse profiles, treatment, and long-term follow-up of patients with gastroparesis. Dig Dis Sci. 1998;43(11):23982404.

4. Christensen CJ, Johnson WD, Abell TL. Patients with cyclic vomiting pattern and diabetic gastropathy have more migraines, abnormal electrogastrograms, and gastric emptying. Scand J Gastroenterol. 2008;43(9):1076-1081.

5. Lobrano A, Blanchard K, Rock W, Johnson W, Schmieg B, Borman K, Araghizadeh F, et al. Assessing thrombosis risk in patients with idiopathic, diabetic, and postsurgical gastroparesis. Adv Ther. 2006;23(5):750-768.

6. Creel WB, Abell TL, Lobrano A, Deitcher SR, Dugdale M, Smalley D, Johnson WD. To clot or not to clot: are there predictors of clinically significant thrombus formation in patients with gastroparesis and prolonged IV access? Dig Dis Sci. 2008;53(6):1532-1536.

7. Kendall BJ, McCallum RW. Gastroparesis and the current use of prokinetic drugs. Gastroenterologist. 1993;1(2):107-114.

8. Parkman HP, Hasler WL, Fisher RS, American Gastroenterological A. American Gastroenterological Association medical position statement: diagnosis and treatment of gastroparesis. Gastroenterology. 2004;127(5):1589-1591.

9. Pareek N, Fleisher DR, Abell T. Cyclic vomiting syndrome: what a gastroenterologist needs to know. Am J Gastroenterol. 2007;102(12):2832-2840.

10. Abell TL, Williams JC. Does maternal predominance exist in the cyclic vomiting pattern in gastroparesis? [ABSTRACT]. Am J Gastroenterol. 2007;102(S2):S507 \#1060.

11. Gotfried J, Schey R. Understanding the differences between gastroparesis and gastroparesis-like syndrome: Filling a GaPing Hole? Dig Dis Sci. 2017;62(10):26152617.

12. Bashashati M, Moraveji S, Torabi A, Sarosiek I, Davis BR, Diaz J, McCallum RW. Pathological findings of the antral and pyloric smooth muscle in patients with gastroparesis-like syndrome compared to gastroparesis: similarities and differences. Dig Dis Sci. 2017;62(10):28282833.

13. Liu N, Abell T. Gastroparesis Updates on Pathogenesis and Management. Gut Liver. 2017;11(5):579-589.

14. Murray D, Abell T. Neural control of the gastrointestinal system. Neuromodulation. 2018:1373-1378.

15. Vanormelingen C, Tack J, Andrews CN. Diabetic gastroparesis. Br Med Bull. 2013;105:213-230.

16. Lal N, Livemore S, Dunne D, Khan I. Gastric Electrical Stimulation with the Enterra System: A Systematic Review. Gastroenterol Res Pract. 2015;2015:762972.

17. Kong M, Wang K, Dong R, Gao H. Enzyme catalytic nitration of aromatic compounds. Enzyme Microb Technol. 2015;73-74:34-43.

18. Chu H, Lin Z, Zhong L, McCallum RW, Hou X. Treatment of high-frequency gastric electrical stimulation for gastroparesis. J Gastroenterol Hepatol. 2012;27(6):10171026.

19. Levinthal DJ, Bielefeldt K. Systematic review and metaanalysis: Gastric electrical stimulation for gastroparesis. Auton Neurosci. 2017;202:45-55. 
20. O'Grady G, Egbuji JU, Du P, Cheng LK, Pullan AJ, Windsor JA. High-frequency gastric electrical stimulation for the treatment of gastroparesis: a meta-analysis. World J Surg. 2009;33(8):1693-1701.

21. Ducrotte P, Coffin B, Mathieu N, et al. Gastric electrical stimulation (ges) for refractory vomiting: results of a prospective multicenter double-blinded randomized controlled cross-over trial. Gastroenterology. 2017;152(5):S167.

22. Abell T, McCallum R, Hocking M, Koch K, Abrahamsson H, Leblanc I, Lindberg G, et al. Gastric electrical stimulation for medically refractory gastroparesis. Gastroenterology. 2003;125(2):421-428.

23. Abell TL, Johnson WD, Kedar A, Runnels JM, Thompson J, Weeks ES, Minocha A, et al. A double-masked, randomized, placebo-controlled trial of temporary endoscopic mucosal gastric electrical stimulation for gastroparesis. Gastrointest Endosc. 2011;74(3):496-503 e493.

24. Abell TL, McCallum RW, May KP, et al. Effectiveness of gastric electrical stimulation in gastroparesis: results from a large prospectively collected database of a national gastroparesis registry (Abstract). Gastroenterology. 2015;148(4):S65.

25. Luo J, Al-Juburi A, Rashed H, O'Dorisio T, Marchal B, Starkebaum W, Abell TL. Gastric electrical stimulation is associated with improvement in pancreatic exocrine function in humans. Pancreas. 2004;29(2):e41-44.

26. McCallum RW, Sarosiek I, Parkman HP, Snape W, Brody F, Wo J, Nowak T. Gastric electrical stimulation with Enterra therapy improves symptoms of idiopathic gastroparesis. Neurogastroenterol Motil. 2013;25(10):815e636.

27. McCallum RW, Snape W, Brody F, Wo J, Parkman HP, Nowak T. Gastric electrical stimulation with Enterra therapy improves symptoms from diabetic gastroparesis in a prospective study. Clin Gastroenterol Hepatol. 2010;8(11):947-954; quiz e116.

28. Cutts TF, Luo J, Starkebaum W, Rashed H, Abell TL. Is gastric electrical stimulation superior to standard pharmacologic therapy in improving GI symptoms, healthcare resources, and long-term health care benefits? Neurogastroenterol Motil. 2005;17(1):35-43.

29. Abell TL, Chen J, Emmanuel A, Jolley C, Sarela AI, Tornblom H. Neurostimulation of the gastrointestinal tract: review of recent developments. Neuromodulation. 2015;18(3):221-227; discussion 227.

30. Grover M, Farrugia G, Lurken MS, Bernard CE, Faussone-Pellegrini MS, Smyrk TC, Parkman HP, et al. Cellular changes in diabetic and idiopathic gastroparesis. Gastroenterology. 2011;140(5):1575-1585 e1578.

31. Singh S, McCrary J, Kedar A, Weeks S, Beauerle B, Weeks A, Endashaw O, et al. Temporary endoscopic stimulation in gastroparesis-like syndrome. J Neurogastroenterol Motil. 2015;21(4):520-527.

32. Appendix A: Rome IV Diagnostic Criteria for Functional Gastrointestinal Disorders. Rome IV Multidimensional Clinical Profile.

33. Janssen P, van Oudenhove L, Bisschops R, Tack J. Idiopathic gastroparesis or functional dyspepsia with delayed gastric emptying: where is the difference? Gastroenterology. 2011;140(7):2145-2146; author reply 2146-2148.

34. Anaparthy R, Pehlivanov N, Grady J, Yimei H, Pasricha PJ. Gastroparesis and gastroparesis-like syndrome: response to therapy and its predictors. Dig Dis Sci. 2009;54(5):1003-1010.

35. Xue HB, Fan HZ, Meng XM, Cristofaro S, Mekaroonkamol P, Dacha S, Li LY, et al. Fluoroscopy-guided gastric peroral endoscopic pyloromyotomy (G-POEM): a more reliable and efficient method for treatment of refractory gastroparesis. Surg Endosc. 2017;31(11):4617-4624.

36. Camilleri M, Szarka LA. POEMs for gastroparesis. Gastrointest Endosc. 2017;85(1):129-131.

37. Dacha S, Mekaroonkamol P, Li L, Shahnavaz N, Sakaria $\mathrm{S}$, Keilin S, Willingham F, et al. Outcomes and quality-of-life assessment after gastric per-oral endoscopic pyloromyotomy (with video). Gastrointest Endosc. 2017;86(2):282-289.

38. Szarka LA, Gostout CJ. Expanding submucosal endoscopy with applied knowledge. Gastrointest Endosc. 2017;85(1):140-142. 